\title{
Kajian Aspek Reproduksi Ikan Lais Ompok hypophthalmus di Sungai Kampar, Kecamatan Langgam, Kabupaten Pelalawan, Provinsi Riau
}

\author{
Roza Elvyra ${ }^{1^{*}}$, Dedy Duryadi Solihin ${ }^{2)}$, Ridwan Affandi ${ }^{3)}$, dan Zairin Junior ${ }^{4)}$ \\ 1)Program Studi Biologi, Fakultas Matematika IImu Pengetahuan Alam, Universitas Riau, 28293 \\ ${ }^{2}$ Departemen Biologi, Fakultas Matematika IImu Pengetahuan Alam, Institut Pertanian Bogor, 16680 \\ ${ }^{3)}$ Departemen Manajemen Sumberdaya Perairan, \\ Fakultas Perikanan IImu Kelautan, Institut Pertanian Bogor, 16680 \\ ${ }^{4)}$ Departemen Budidaya Perikanan, Fakultas Perikanan Ilmu Kelautan, Institut Pertanian Bogor, 16680
}

Diterima 28-04-1009 Disetujui 20-10-2009

\begin{abstract}
Lais fish of Ompok hypophthalmus is one of high economic fish in Kampar river. It should be protected from decreasing of it population estimated due to decreasing of habitat quality and increasing of exploitation. The objectives of the research are to study reproduction biology of lais fish as the basic data for conservation. This research was conducted from January 2007 to January 2008. The results of 0 . hypophthalmus reproduction aspect show that the smallest female of maturity is $22,9 \mathrm{~cm}$ and male is $22,6 \mathrm{~cm}$; the spawning season on September to November; 0 . hypophthalmus is more appropriate spawning location to oxbow lake that close relation with tributary; the spawning pattern indicated total spawner fish; the fecundity ranges from 3111 to 11164 eggs and the egg diameter ranges $0,41-1,13 \mathrm{~mm}$.
\end{abstract}

Keywords : Kampar river, Ompok hypophthalmus, oxbow lake, reproduction

\section{PENDAHULUAN}

Provinsi Riau memiliki potensi ekosistem sungai rawa banjiran yang dikenal juga dengan istilah sungai paparan banjir atau floodplain river dengan keragaman jenis ikannya yang tinggi. Salah satu ekosistem sungai rawa banjiran di Provinsi Riau ada di kecamatan Langgam Sungai Kampar. Sungai Kampar telah ditetapkan sebagai pusat produksi perikanan air tawar di Provinsi Riau dengan SK Gubernur No. 99/II/2000.

Ekosistem sungai rawa banjiran sebagai habitat ikan, kompleks dengan sungai, anak sungai dan danau banjiran atau oxbow lakeyang mempunyai fungsi untuk kelangsungan hidup ikan. Lubuk pada dasar sungai digunakan ikan sebagai tempat berlindung. Anak sungai terutama pada bagian pinggirnya, digunakan ikan sebagai tempat berlindung dan mencari makan. Danau banjiran yang mempunyai vegetasi riparian yang terendam, digunakan oleh ikan sebagai tempat memijah sekaligus juga tempat mencari makan dan berlindung (Hartoto et al., 1998).

\footnotetext{
*Telp: +6285217461508

Email: roza_elvyra@yahoo.com
}

Di antara ikan yang hidup pada ekosistem sungai rawa banjiran di Sungai Kampar Riau, ada jenis-jenis ikan dari genus Kryptopterus dan Ompok yang termasuk famili Siluridae yang secara umum di Indonesia dikenal sebagai ikan lais (Utomo et al. 1990, Kottelat et al., 1993, Fishbase 2008), atau di Provinsi Riau dikenal sebagai ikan selais (Pulungan et al., 1985, Saberina \& Nuraini 2005). Genus Ompok di Indonesia terdiri dari 7 jenis, sedangkan genus Kryptopterus di Indonesia terdiri dari 14 jenis (Kottelat el al., 1993). Ikan lais Ompok mempunyai nama sinonim Silurodes, sedangkan Kryptopterus mempunyai nama sinonim Cryptopterus (Weber \& Beaufort 1913, Kottelat et al., 1993). Salah satu jenis dari ikan lais tersebut adalah Ompok hypophthalmus, yang dikenal secara spesifik oleh masyarakat di sekitar S. Kampar sebagai ikan lais danau. Ikan lais $O$. hypophthalmus termasuk ikan air tawar yang dikonsumsi masyarakat dan mempunyai nilai ekonomis tinggi.

Produksi ikan lais di provinsi Riau belakangan ini mengalami penurunan. Kondisi ini disebabkan pencemaran lingkungan dan pendangkalan sungai, 
serta tingkat penangkapan yang cenderung telah berada pada tingkat maksimal, terutama di sepanjang muara sungai dan danau-danau dekat daerah perkampungan (Diskanlut Provinsi Riau 2007). Usaha konservasi sangat perlu dilakukan dalam upaya pemanfaatan sumber daya perairan sungai yang berkelanjutan. Usaha tersebut akan lebih terarah dan berhasil secara maksimal, apabila informasi fundamental mengenai ikan lais digali lebih dalam dan rinci. Salah satu informasi yang sangat diperlukan adalah aspek reproduksi ikan lais.

Walaupun informasi tentang aspek reproduksi ikan lais sudah ada (Elvyra 2000, Simanjuntak 2007), tapi hanya bersifat penelitian yang terpotong-potong dalam waktu yang pendek. Informasi rincinya dalam periode satu tahun sangat dibutuhkan. Oleh sebab itu perlu dilakukan penelitian lebih rinci untuk mendapatkan informasi fluktuasi aspek reproduksi. Informasi aspek reproduksi akan memberikan gambaran kemampuan suatu spesies dalam melangsungkan kehidupan dan perkembangannya dari waktu ke waktu.

Berdasarkan hal tersebut di atas maka tujuan penelitian ini adalah untuk mengkaji aspek reprodusi ikan lais $O$. hypophthalmus dalam periode satu tahun yang meliputi ukuran ikan terkecil mencapai matang gonad, musim pemijahan, lokasi pemijahan, pola pemijahan dan potensi reproduksi. Manfaat dari penelitian ini diharapkan dapat menjadi landasan untuk usaha konservasi dalam upaya pemanfaatan sumber daya perairan yang berkelanjutan pada ekosistem sungai rawa banjiran, khususnya terhadap ikan lais $O$. hypophthalmus di Sungai Kampar Riau.

\section{BAHAN DAN METODE}

Waktu dan Tempat Penelitian. Penelitian dilakukan mulai dari bulan Januari 2007 sampai Januari 2008 dengan lokasi pengambilan sampel di Sungai Kampar, Kecamatan Langgam, Kabupaten Pelalawan, Provinsi Riau. Analisis aspek reproduksi ikan lais dilakukan di Laboratorium Ekologi, Jurusan BiologiFMIPA, UNRI.

Stasiun Penelitian. Stasiun penelitian terdiri dari 3 stasiun. Stasiun I adalah sungai yaitu Langgam. Stasiun ini merupakan pertemuan S. Kampar Kiri dan S. Kampar Kanan. Lebar S. Langgam \pm 125 meter. Lokasi yang dipilih adalah yang berhubungan dengan Danau Sarang Janggut ( \pm lebar 30 meter). Aliran yang menghubungkan sungai dengan Danau Sarang Janggut pada musim kemarau tidak terputus, tetapi dangkal ( \pm 1 meter).

Stasiun II adalah anak sungai yaitu Segati. Lebar anak sungai Segati \pm 70 meter. Lokasi yang dipilih adalah yang berhubungan dengan Danau Sarang Penyangek ( \pm lebar 20 meter). Pada musim kemarau, aliran yang menghubungkan anak sungai Segati dengan danau ini terputus.

Stasiun III adalah Danau Kejuit. Stasiun ini merupakan danau besar (lebar \pm 100 meter). Aliran S. Kampar dengan Danau Kejuit pada musim kemarau tidak terputus (kedalaman \pm 3 meter). Peta lokasi

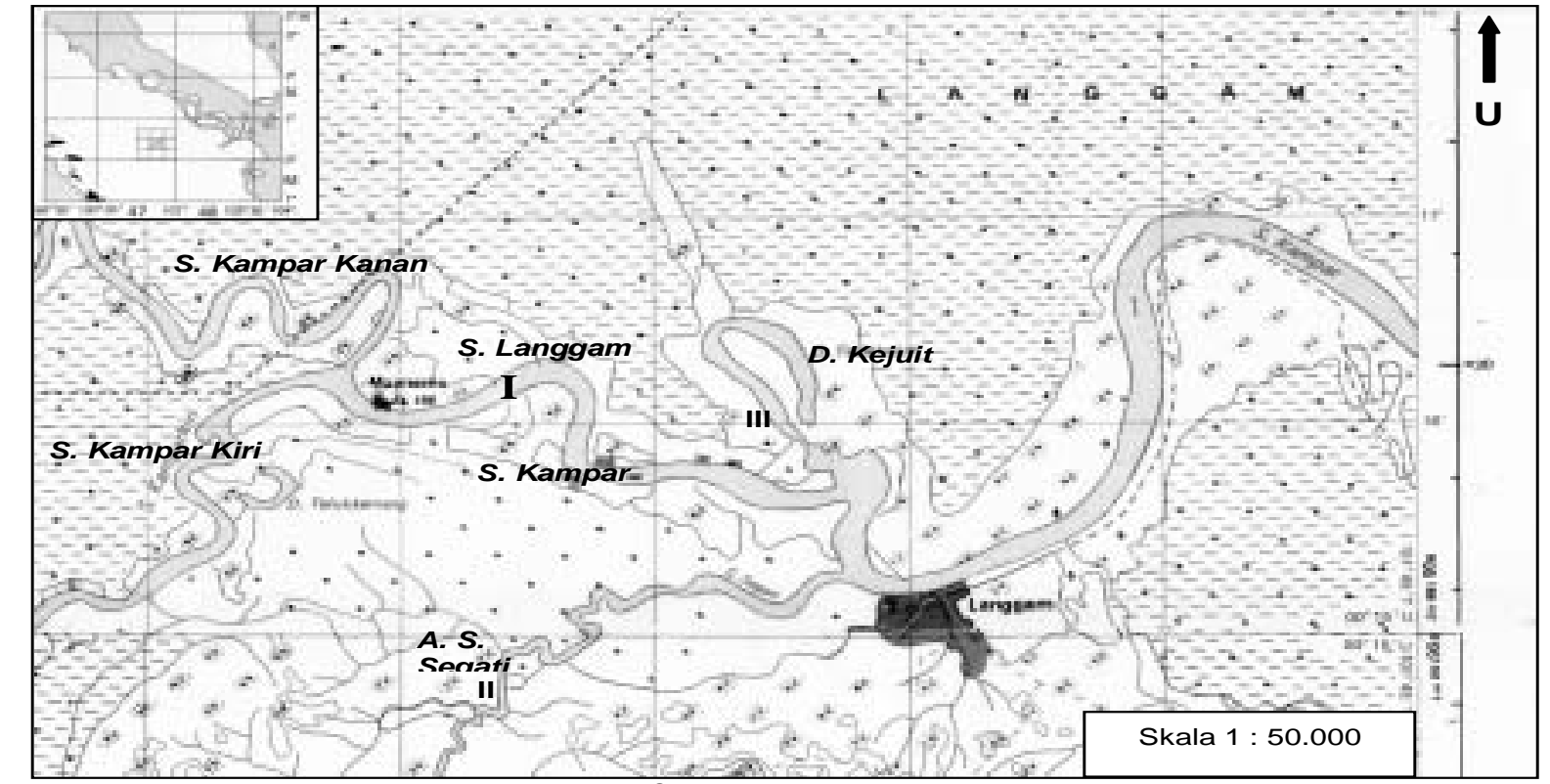

Gambar 1. Peta lokasi pengambilan sampel ikan lais di Sungai Kampar, Kecamatan Langgam, Kabupaten Pelalawan, Provinsi Riau (Sumber : Bakosurtanal 1984) 
pengambilan sampel ikan lais di Sungai Kampar disajikan pada Gambar 1.

Prosedur Penelitian. Sampel ikan lais ditangkap dengan menggunakan jaring insang dengan ukuran mata jaring 0,$75 ; 1 ; 1,25 ; 1,5 ; 1,75 ; 2$ inci dan alat tangkap sempirai (perangkap), pada setiap lokasi pengambilan sampel. Jaring insang dipasang di perairan pada jam 18.00 WIB sore dan diangkat kembali pada jam 6.00 WIB pagi hari berikutnya, sedangkan sempirai dipasang di perairan selama dua hari dua malam. Sampel koleksi ikan lais O. hypophthalmus diidentifikasi berdasarkan acuan Kottelat et al., (1993); $\mathrm{Ng}$ (2003) dan FishBase (2008). Koleksi sampel ikan lais dilakukan setiap bulan selama satu tahun pada setiap lokasi penelitian. Apabila yang tertangkap lebih dari 100 ekor, diambil 30 ekor ikan lais yang terdiri dari kelompok ukuran kecil, sedang dan besar masingmasing 10 ekor. Apabila yang tertangkap kurang dari 100 ekor, maka diambil semua dari jumlah yang tertangkap. Sampel ikan lais dalam keadaan segar diukur panjang tubuhnya dengan menggunakan mistar dan ditimbang berat tubuhnya dengan timbangan digital.

Karakteristik perkembangan gonad ikan lais ditentukan berdasarkan tingkat kematangan gonad (TKG) secara morfologis menurut modifikasi Cassie (Effendie 1992). Perkembangan gonadnya digolongkan dalam lima tahap yaitu TKG I (belum berkembang), II (perkembangan awal), III (sedang berkembang), IV (matang gonad) dan $V$ (pasca pemijahan). Indeks kematangan gonad (IKG) dihitung berdasarkan persentase dari perbandingan berat gonad dengan berat tubuh ikan termasuk gonad (Yalcin et al., 2001). Fekunditas dihitung sebagai jumlah telur yang terdapat dalam ovari ikan lais betina yang telah mencapai matang gonad (TKG IV) berdasarkan metode gravimetrik (Effendi 1992). Diameter telur pada ikan lais yang matang gonad diketahui dengan cara mengambil 150 butir telur dari tiga bagian subsampel ovari (bagian anterior, tengah, posterior yaitu masing-masingnya 50 butir). Diameter telur-telur tersebut diukur dengan menggunakan mikrometer okuler pada mikroskop.

Analisis Data. Ukuran ikan lais terkecil mencapai matang gonad ditentukan berdasarkan data TKG dikaitkan dengan data ukuran ikan. Musim pemijahan ikan lais dianalisis berdasarkan data tingkat kematangan gonad dan indeks kematangan gonad, dikaitkan dengan bulan pengambilan sampel selama satu tahun. Lokasi pemijahan ikan lais dianalisis berdasarkan data tingkat kematangan gonad dikaitkan dengan lokasi pengambilan sampel di Sungai Kampar. Pola pemijahan ikan lais dianalisis berdasarkan data tingkat kematangan gonad, indeks kematangan gonad, dan diameter telur ikan lais betina yang matang gonad. Potensi reproduksi dianalisis berdasarkan data fekunditas dan diameter telur ikan lais betina yang matang gonad.

\section{HASIL DAN PEMBAHASAN}

Ukuran Ikan Terkecil Matang Gonad. Sampel ikan lais $O$. hypophthalmus yang diperoleh di S. Kampar dari bulan Januari 2007 hingga Januari 2008, berjumlah 1049 ekor yang terdiri dari 685 ekor ikan lais betina dan 364 ekor ikan lais jantan. Ikan lais dari stasiun Langgam berjumlah 338 ekor terdiri dari 212 betina dan 126 jantan, dari stasiun Segati berjumlah 373 ekor terdiri dari 254 betina dan 119 jantan, dan dari stasiun Kejuit berjumlah 338 ekor terdiri dari 219 betina dan 119 jantan.

Kisaran ukuran panjang dan berat tubuh dari keseluruhan sampel ikan lais betina adalah 12,7-28,0 cm dan 9,33-106,84 g, sedangkan ikan lais jantan 13,9$28,6 \mathrm{~cm}$ dan 10,25-116,82 g. Berdasarkan pengamatan tingkat kematangan gonad terhadap 1049 ekor ikan lais tersebut, panjang dan berat tubuh ikan lais betina terkecil mencapai matang gonad (TKG IV) adalah 22,9 $\mathrm{cm}$ dan $53,66 \mathrm{~g}$, sedangkan ikan lais jantan pada panjang 22,6 cm dan berat 48,04 g.

Tingkat Kematangan Gonad Berdasarkan Waktu dan Stasiun Penelitian. Hasil penelitian persentase tingkat kematangan gonad (TKG) ikan lais O. hypophthalmus betina dan jantan mulai Januari 2007 hingga Januari 2008 memperlihatkan bahwa TKG IV dijumpai pada bulan September dan Oktober. Persentase TKG IV tertinggi dari ikan lais betina $(18,33 \%)$ terjadi pada bulan Oktober dan persentase terendah $(4,08 \%)$ terjadi pada bulan September. Sementara itu, TKG IV ikan lais jantan dijumpai pada bulan September, Oktober dan November. Persentase TKG IV tertinggi dari ikan lais jantan (36,67\%) terjadi pada bulan Oktober dan persentase terendah (4,35\%) terjadi pada bulan November, seperti tertera pada Gambar 2. Berdasarkan hasil penelitian persentase TKG IV ikan lais betina dan jantan tersebut, terlihat bahwa ikan lais mempunyai satu kali musim pemijahan dalam setahun. Musim pemijahan mulai terjadi pada 
Tabel 1. Uji Mann-Whitney terhadap jumlah ikan lais Ompok hypophthalmus betina dan jantan matang gonad (TKG IV) pada stasiun Langgam, Segati dan Kejuit

\begin{tabular}{|c|c|c|c|c|c|c|}
\hline \multirow{3}{*}{$\begin{array}{l}\text { Jumlah betina dan jantan matang gonad } \\
\text { pada ketiga stasiun yang dibandingkan }\end{array}$} & \multicolumn{6}{|c|}{ Nilai Mann-Whitney (a) } \\
\hline & \multicolumn{3}{|c|}{ Ikan Betina } & \multicolumn{3}{|c|}{ Ikan Jantan } \\
\hline & I & II & III & $\mathrm{I}$ & II & III \\
\hline $\mathrm{I}$ & - & 0,6625 & 1,0000 & - & 0,8723 & 1,0000 \\
\hline II & & - & 0.5127 & & - & 0,6625 \\
\hline III & & & - & & & - \\
\hline
\end{tabular}

Keterangan: $\alpha>0,05$ = tidak berbeda nyata; I = Langgam; II = Segati; III = Kejuit

Betina $(\mathrm{N}=685)$

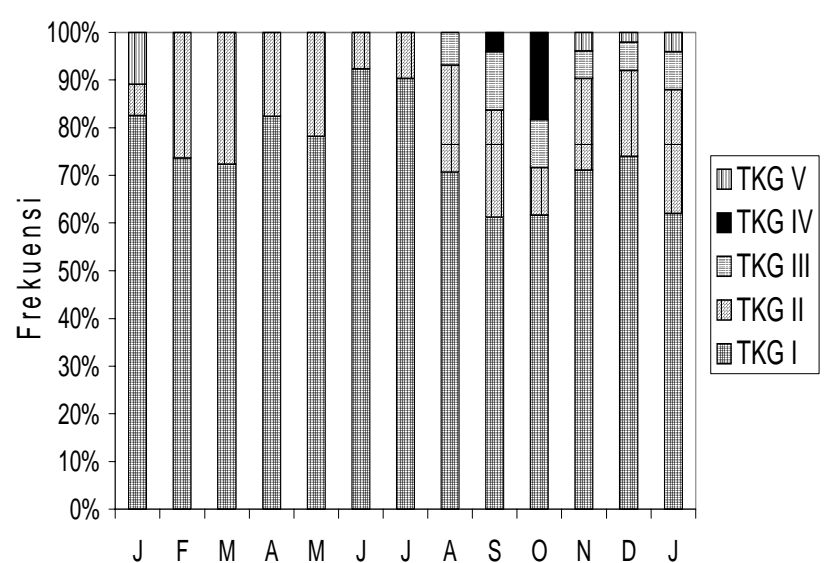

Jantan ( $\mathrm{N}=364)$

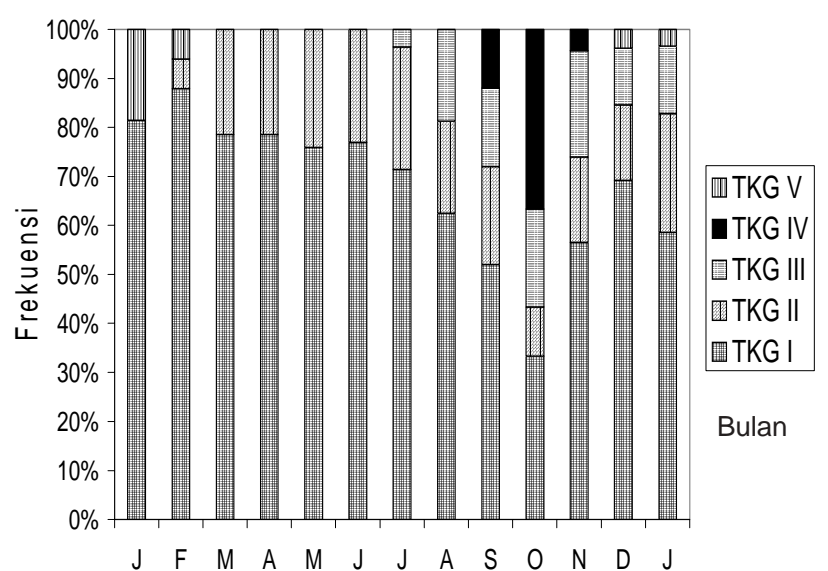

Gambar 2. Persentase tingkat kematangan gonad ikan lais Ompok hypophthalmus berdasarkan waktu penelitian di lingkungan Sungai Kampar

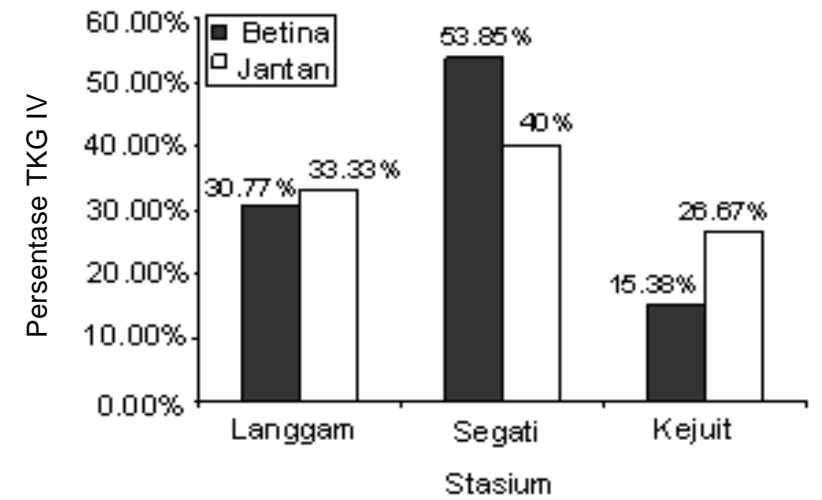

Gambar 3. Persentase TKG IV ikan lais Ompok hypophthalmus berdasarkan stasiun penelitian di lingkungan Sungai Kampar

saat mulai masuknya musim hujan yaitu bulan September, berlanjut hingga bulan Oktober dan November. Persentase TKG IV ikan lais betina dan jantan yang tertinggi terjadi pada bulan Oktober. Selanjutnya, TKG V ikan lais betina dijumpai pada bulan November, Desember dan Januari, sedangkan TKG V ikan lais jantan dijumpai pada bulan Desember dan Januari.

Tingkat kematangan gonad (TKG) IV adalah puncak kematangan gonad ikan karena ikan dalam kondisi siap memijah. Gambar 3 memperlihatkan persentase dari jumlah keseluruhan ikan lais betina dan jantan yang matang gonad (TKG IV) pada masingmasing stasiun. Persentase ikan lais yang matang gonad pada stasiun Segati terlihat relatif lebih tinggi baik pada ikan betina maupun ikan jantan dibandingkan stasiun lainnya. Jika ketiga stasiun dibandingkan berdasarkan uji Mann-Whitney (Tabel 1), didapatkan persentase dari jumlah ikan lais betina maupun jantan yang matang gonad antara stasiun Langgam, Segati dan Kejuit adalah tidak berbeda nyata (á > 0,05).

Stasiun Segati adalah anak sungai yang berhubungan dengan danau banjiran yaitu Danau Sarang Penyangek. Pada musim kemarau, aliran yang menghubungkan anak sungai Segati dengan danau ini terputus, sedangkan pada musim hujan alirannya dapat bersambung kembali. Hal ini menunjukkan adanya hubungan yang kuat antara perilaku pemijahan dengan keberadaan danau banjiran dan kondisi curah hujan.

Pada saat ketinggian air mulai meningkat seiring naiknya curah hujan, para nelayan di S. Kampar memasang alat tangkap berupa sempirai (perangkap) pada jalur aliran sungai / anak sungai ke danau banjiran yang mulai bersambungan kembali. Sempirai sering digunakan oleh nelayan di S. Kampar, jika keadaan air sungai / anak sungai dari keadaan sangat surut berlanjut hingga ketinggian air berangsur-angsur naik seiring masuknya musim hujan. Pada saat permukaan perairan mulai naik, nelayan memasang sempirai sehingga ikanikan yang menuju danau banjiran akan banyak tertangkap. Pada saat tersebut, ikan-ikan yang akan memijah (TKG IV) akan tertangkap. 
Pada saat permukaan perairan naik pada musim penghujan, ketersediaan makanan di danau dan rawa banjiran akan melimpah sehingga akan merangsang ikan-ikan untuk mempercepat pematangan gonad. Proses pematangan gonad sangat erat kaitannya dengan sinyal-sinyal lingkungan seperti ketersediaan makanan untuk anak-anak ikan nantinya. Selain itu, adanya substansi petrichor ketika permukaan perairan naik (flood) yang membasahi dataran yang kering setelah musim kemarau merupakan trigger untuk proses pemijahan (Van der Wall 2006).

Indeks Kematangan Gonad (IKG). Rata-rata nilai IKG ikan lais $O$. hypophthalmus betina dari bulan Januari 2007 hingga Januari 2008 berkisar antara 0,09-1,44\%, sedangkan IKG ikan lais jantan berkisar antara 0,06$0,28 \%$. Nilai IKG ikan lais betina dan jantan terlihat jelas meningkat dari bulan September hingga Oktober 2007 dan menurun pada bulan November 2007 (Gambar 4). Peningkatan nilai IKG tersebut seiring dengan mulai masuknya musim hujan pada bulan September dan Oktober 2007, dan mulai meningkatnya curah hujan

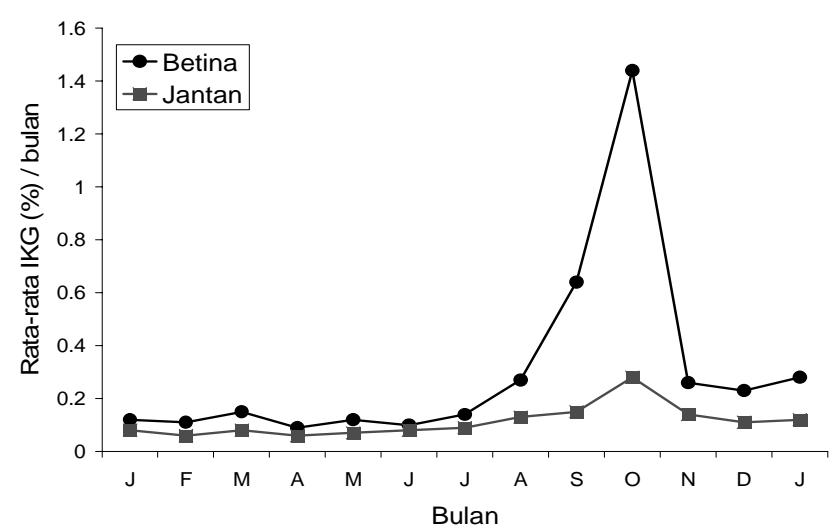

Gambar 4. Grafik rata-rata nilai indeks kematangan gonad ikan lais Ompok hypophthalmus betina dan jantan berdasarkan waktu pengamatan (bulan Januari 2007 sampai dengan Januari 2008) maupun lamanya hari hujan dalam sebulan. Curah hujan bulan September 2007 di Kabupaten Pelalawan yaitu $73,5 \mathrm{~mm}$ dengan lama hujan 16 hari dan pada bulan Oktober 2007 curah hujan $\quad 328,5 \mathrm{~mm}$ dengan lama hujan 21 hari (BMG Pekanbaru 2007).

Adanya puncak kurva IKG pada bulan Oktober menunjukkan bahwa ikan lais di S. Kampar dalam penelitian ini mempunyai satu musim pemijahan dalam satu tahun yang bergantung kepada masuknya musim hujan. Pola pemijahan ikan lais yang mempunyai satu musim pemijahan dalam setahun jika dihubungkan dengan pendapat Lowe-McConnel (1987), termasuk pola total spawner.

Fekunditas dan Diameter Telur. Fekunditas dari ikan lais $O$. hypophthalmus yang matang gonad dengan ukuran panjang total $22,9-28,0 \mathrm{~cm}$ dan berat total $53,66-94,03 \mathrm{~g}$ adalah sebanyak $3111-11164$ butir. Secara keseluruhan, hubungan antara fekunditas dengan panjang dan berat total ikan lais ditentukan dengan persamaan : $\mathrm{F}=-5097+472.1 \mathrm{PT}(\mathrm{r}=0,304)$ dan $\mathrm{F}=1740+65.91 \mathrm{BT}(\mathrm{r}=0,337)$.

Perbedaan fekunditas disebabkan adanya variasi ukuran panjang dan berat total tubuh ikan pada TKG IV. Nilai korelasi persamaan garis antara fekunditas ikan lais dengan panjang total tubuh adalah 0,304, sedangkan nilai korelasi antara fekunditas dengan berat total tubuh adalah 0,337 . Nilai korelasi antara fekunditas dengan berat total tubuh ikan lais cenderung lebih tinggi dibandingkan dengan korelasi antara fekunditas dengan panjang total tubuh. Namun secara keseluruhan, nilai korelasi antara fekunditas ikan lais dengan panjang dan berat total tubuh termasuk nilai yang rendah.

Hasil pengukuran diameter telur ikan lais selama penelitian berkisar 0,41-1,13 mm. Dari Gambar 5 terlihat bahwa kurva sebaran diameter telur cenderung

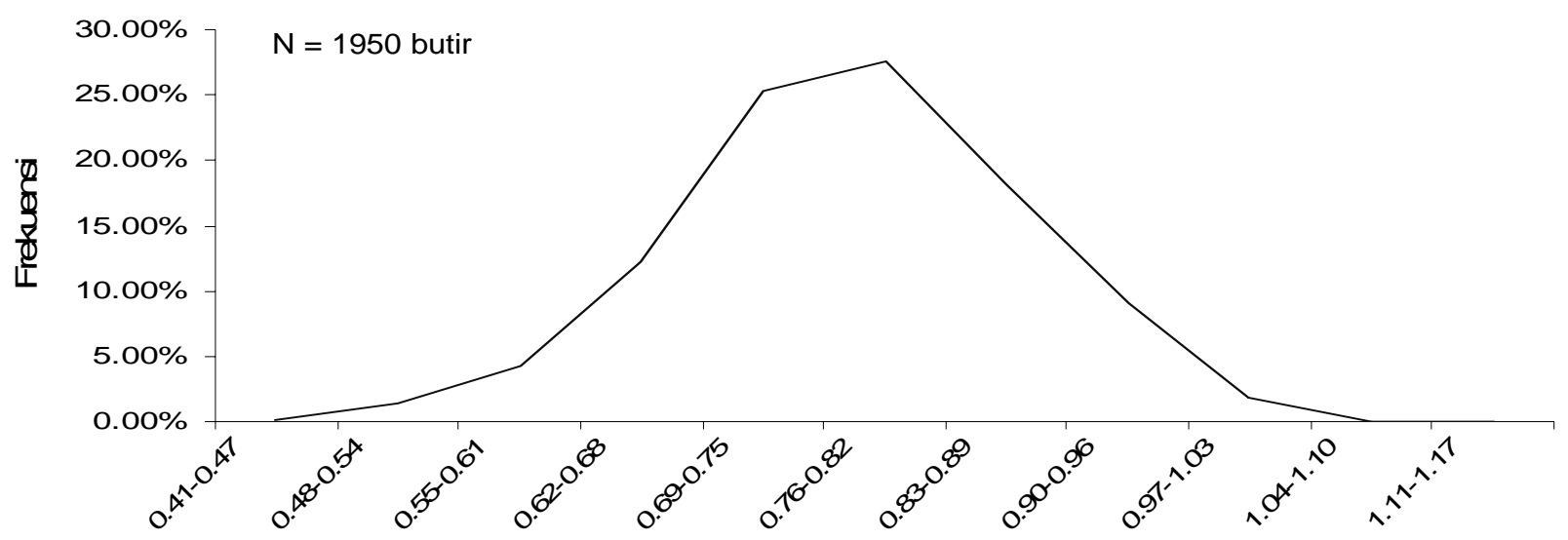

Selang diameter telur $(\mathrm{mm})$

Gambar 5. Pola sebaran diameter telur ikan lais Ompok hypophthalmus di Sungai Kampar 
Tabel 2. Uji Mann-Whitney terhadap ukuran diameter telur pada ovari bagian anterior, tengah dan posterior ikan lais Ompok hypophthalmus

\begin{tabular}{cccc}
\hline Ukuran diameter telur pada bagian ovari & & Nilai Mann-Whitney $(\alpha)$ & Posterior \\
\cline { 2 - 4 } yang dibandingkan & Anterior & Tengah & 0,3191 \\
Anterior & - & 0,0732 & 0,5144 \\
Tengah & & - & - \\
Posterior & & &
\end{tabular}

memiliki satu puncak kurva. Sementara itu, berdasarkan uji Mann-Whitney (Tabel 2) didapatkan ukuran diameter telur pada ovari bagian anterior, tengah maupun posterior adalah tidak berbeda nyata (á $>0,05$ ). Ukuran telur yang relatif seragam antara ovari bagian anterior, tengah dan posterior menunjukkan bahwa telur ikan lais matangnya serentak. Berdasarkan kurva sebaran diameter telur pada ovari dan nilai uji MannWhitney, memperkuat bukti bahwa ikan lais mengeluarkan telur matangnya secara serentak dalam satu kali periode pemijahan (total spawner) dan periode pemijahan tersebut tidak sepanjang tahun, tetapi tergantung kepada masuknya musim hujan. Ikan yang mempunyai satu musim pemijahan dalam setahun jika dihubungkan dengan dinamika pengorganisasian ovari menurut Wallace dan Selman (1981), tipe perkembangan ovarinya termasuk tipe sinkronous berkelompok.

Usaha konservasi dalam upaya pemanfaatan sumber daya ikan lais yang berkelanjutan. Usaha konservasi mempunyai fungsi utama yaitu sebagai fungsi ekologis dalam menunjang peningkatan populasi alami melalui pemulihan populasi, dan sebagai fungsi sosio ekonomi maupun sosio budaya dalam memenuhi aspek pemanfaatannya bagi kesejahteraaan manusia (Hartoto et al., 1998). Pengelolaan sumber daya perikanan di suatu perairan dapat dilakukan sebagai upaya untuk memperoleh produksi perikanan maksimum yang berkelanjutan, keuntungan ekonomi maksimum yang berkesinambungan bagi para pihak pengguna sumber daya perikanan dan meningkatkan kesejahteraan para pihak yang terkait dengan pemanfaatan sumber daya perikanan, terutama nelayan (King 1997). Strategi pengelolaan perikanan terkait dengan pengaturan ukuran ikan yang boleh ditangkap, pengaturan jenis alat, waktu dan lokasi penangkapan.

Penentuan ukuran ikan yang boleh ditangkap didasarkan atas pertimbangan ikan yang telah mampu melakukan reproduksi untuk regenerasi atau kelangsungan keturunannya. Ukuran ikan lais $O$. hypophthalmus betina terkecil mencapai matang gonad yang ditemukan di S. Kampar selama penelitian adalah
$22,9 \mathrm{~cm}$, sedangkan pada ikan jantan adalah $22,6 \mathrm{~cm}$. Berdasarkan ukuran ikan lais $O$. hypophthalmus terkecil mencapai matang gonad yang ditemukan di S. Kampar tersebut, penentuan ukuran ikan lais betina yang boleh ditangkap adalah $>22,9 \mathrm{~cm}$ dan ikan lais jantan $>22,6 \mathrm{~cm}$.

Dari hasil penelitian, terlihat bahwa ikan lais $O$. hypophthalmus mempunyai satu kali musim pemijahan dalam setahun yaitu pada saat mulai naiknya curah hujan yaitu bulan September, berlanjut hingga bulan Oktober dan November. Lokasi pemijahan yang paling disukai adalah danau banjiran yang bersambungan kembali dengan anak sungai pada musim hujan. Pengaturan penutupan lokasi pemijahan selama musim pemijahan perlu dilakukan untuk mengurangi penurunan kepadatan populasi ikan. Hal ini dapat dilakukan dengan melibatkan nelayan untuk berpartisipasi menjaga kelestarian ikan.

Di Sungai Kampar khususnya di Kecamatan Langgam Kabupaten Pelalawan, masyarakat mempunyai cara tersendiri untuk pengaturan penangkapan ikan dengan sistim lelang danau yaitu danau-danau yang produktif dapat disewa per tahun oleh kelompok nelayan tertentu dan hanya kelompok nelayan tersebut yang boleh menangkap ikan di danaudanau tersebut. Tetapi usaha tersebut diperkirakan kurang maksimal, kalau tanpa dibarengi usaha pengaturan pemakaian alat tangkap ikan selama musim pemijahan. Alat tangkap ikan berupa sempirai (perangkap) sebaiknya tidak dilakukan pada jalur sungai/anak sungai ke danau banjiran pada musim pemijahan, sehingga induk-induk ikan lais tidak terganggu untuk melangsungkan reproduksinya. Hal ini perlu diperhatikan dalam upaya pemanfaatan sumber daya ikan lais yang berkelanjutan.

\section{KESIMPULAN}

Berdasarkan hasil penelitian dan pembahasan yang telah dilakukan, dapat disimpulkan:

Ukuran ikan lais $O$. hypophthalmus betina terkecil mencapai matang gonad pada ukuran panjang $22,9 \mathrm{~cm}$, sedangkan ikan lais jantan pada panjang $22,6 \mathrm{~cm}$. 
Musim pemijahan ikan lais $O$. hypophthalmus pada bulan September hingga November. Lokasi pemijahan yang lebih disukai ikan lais $O$. hypophthalmus adalah danau banjiran yang berhubungan dengan anak sungai. Pola pemijahan ikan lais $O$. hypophthalmus adalah total spawner. Potensi reproduksi ikan lais $O$. hypophthalmus meliputi fekunditas sebanyak 3111-11164 butir dengan diameter telur berkisar 0,41-1,13 mm.

\section{UCAPAN TERIMAKASIH}

Penulis mengucapkan terimakasih kepada Pak Umar sekeluarga di Pelalawan, Yuliadi dan Briek Novayanti yang telah membantu dalam penelitian ini.

\section{DAFTAR PUSTAKA}

Badan Meteorologi. \& Geofisika. 2007. Data curah hujan daerah Pangkalan Kerinci-Pelalawan. Pekanbaru: Stasiun Meteorologi.

Dinas Perikanan. \& Kelautan. 2007. Statistik perikanan tangkap Provinsi Riau. Pekanbaru: Diskanlut Provinsi Riau.

Effendie, M.I. 1992. Metoda biologi perikanan. Bogor: Yayasan Agromedia.

Elvyra, R. 2000. Beberapa aspek ekologi ikan lais Kryptopterus limpok (Blkr.) di Sungai Kampar Kiri Riau. Tesis. Padang: Universitas Andalas.

FishBase. 2008. A global information system on fishes. http:// www.fishbase.org/ (16 Januari 2008).

Hartoto, D.I., Sarnita, A.S., Sjafei, D.S., Satya, A., Syawal, Y. Sulastri, Kamal, M.M. \& Siddik, Y. 1998. Kriteria evaluasi suaka perikanan perairan darat. Pusat Penelitian dan Pengembangan Limnologi. Bogor: Lembaga IImu Pengetahuan Indonesia.
King, M. 1997. Fisheries biology, assessment and management. Fishing News Books. London: A division of Blackwell Science Ltd.

Kottelat, M., Whitten, A.J., Kartikasari, S.N. \& Wirdjoatmodjo, S. 1993. Freshwater fishes of western Indonesia and Sulawesi. Jakarta: Periplus edition (HK) in collaboration with the environment Rep. of Indonesia.

Lowe-McConnell, R.H. 1987. Ecological studies in tropical fish communities. Australia: Cambridge University Press.

$\mathbf{N g}$, H.H. 2003. A review of the Ompok hypophthalmus group of Silurid catfishes with the description of a new species from South-East Asia. J. Fish Biol. 62: 1296-1311.

Pulungan, C.P., Ahmad, M., Siregar, Y.I., Ma'amoen, A. \& Alawi, H. 1985. Morfometrik ikan selais Siluroidea dari perairan Kecamatan Kampar Kiri Kabupaten Kampar Riau. Pekanbaru: Pusat Penelitian Universitas Riau.

Saberina. \& Nuraini. 2005. Ekologi ikan selais (Kryptopterus spp.) di perairan wilayah Pelalawan Riau. Berkala Perikanan Terubuk 32: 40-47.

Simanjuntak, C.P.H. 2007. Reproduksi ikan selais Ompok hypophthalmus (BIkr.) berkaitan dengan perubahan hidromorfologi perairan di rawa banjiran Sungai Kampar Kiri. Tesis. Bogor: Institut Pertanian Bogor.

Utomo, A.D., Adjie, S. \& Asyari. 1990. Aspek biologi ikan lais di perairan Lubuk Lampam Sumatera Selatan. Bulletin Penelitian Perikanan Darat 9: 105-111.

Van der Wall, B.C.W. 2006. Observations on the breeding habits of Clarias gariepinus (Burchell). J. Fish Biol. 6:23-27.

Wallace, R. \& Selman, K. 1981. Cellular and dynamic aspects of oocyte growth in Teleost. Am. Zool. 21: 325-343.

Weber, M. \& De Beaufort, L.F. 1913. The Fish of the IndoAustralian archipelago. Vol. II. Malacopterygii, Myctophoidea, Ostariophysi : I. Siluroidea. Leiden: E.J. Brill Ltd.

Yalcin, S., Solak, K. \& Akyurt, I. 2001. Certain reproductive characteristics of the catfish (Clarias gariepinus Burchell 1822) living in the River Asi Turkey. Turk. J. Zool. 25: 453460. 